\title{
MERANGKAI KONSEP HARGA JUAL BERBASIS NILAI KEADILAN DALAM ISLAM
}

\author{
Alimuddin \\ aan_alimuddin@yahoo.com
}

Fakultas Ekonomi Universitas Hasanuddin

\begin{abstract}
This paper aims to explore and discuss the justice value in Islam in order to formulate price concept based on justice value in Islam. The second aim is to find out the benefits of the price concept for mashlahah of mankind. The analytical method employed in this paper is a critical-intuitive thinking based on Islamic epistemological framework, that is the bayani method, burhani method and irfani method. The bayani mothod is a textual presentation from text, event or phenomenon while the burhani mothod is based on logic to understand events and phenomena or to interpret the text contextually. While irfani mothod places greater reliance on intuition to achieve scientific knowledge. The three methods are applied integratedly in this paper. The study was conducted on the owners and management YDT in Bandung. The results showed, the price concept based on justice value according to bayani method is cost-plus profane basic needs and according to burhani method is cost-plus basic needs as well as according to irfani method is costplus basic needs and environment. In general, the price concept based on justice value in Islam is cost-plus pricing, which is a concept that considers pricing benefit for mashlahah of mankind in determining the amount of margin through a balance between the needs of traders with the basic needs of the buyer's purchasing power and the need to preserve and maintain harmonization of the relationship with the environment. Determination of the price would reduce the economic disparities in society, creating a more harmonious life, and enhance the dignity of mankind.
\end{abstract}

Keywords: justice value, bayani, burhani, irfani, cost-plus pricing.

\section{PENDAHULUAN}

Terjadi perdebatan yang panjang dalam penetapan harga jual yang adil, antara pendapat yang mengatakan bahwa harga sebaiknya diatur oleh pemerintah agar terjadi keseragaman harga dengan harga yang didasarkan pada mekanisme pasar tanpa campur tangan pemerintah. Pendapat pertama berargumentasi bahwa dengan penetapan harga oleh pemerintah akan tercipta keadilan dan kesejahteraan yang merata di dalam 
masyarakat sebagaimana dianut paham sosialis. Sementara pendapat kedua menyatakan bahwa dengan terjadinya penetapan harga berdasarkan mekanisme pasar akan mendorong terjadinya persaingan yang sehat sehingga tercipta efisiensi yang pada akhirnya akan meningkatkan kesejahteraan bersama sebagimana yang dianut paham kapitalisme.

Nabi Muhammad melarang pemerintah ikut campur menetapkan harga jika mekanisme pasar berjalan normal atau pelaku bisnis (penjual dan pembeli) tidak melakukan pelanggaran atau penyimpangan yang mengharuskan munculnya suatu tindakan pengendalian harga (Qardhawi, 2000). Kenaikan harga yang melambung tinggi mendorong masyarakat untuk meminta kepada Rasulullah untuk melakukan tindakan, namun jawaban beliau, "sesungguhnya Allah-lah yang menetapkan harga dan menahan rezeki kepada yang dikehendaki-Nya serta memberikan-Nya kepada yang disukaiNya...”

Dari segi ekonomi, tindakan pemerintah untuk menetapkan harga bukannya untuk menekan harga tetapi dalam jangka menengah dan panjang akan mendorong harga naik atau lebih mahal karena para eksportir atau penjual dari daerah lain tidak akan mau membawa barang dagangannya di bawah harga yang diinginkannya. Sementara para importir dan penjual lokal yang memiliki barang dagangan akan menahan/ menyembunyikan barang dagangannya karena berlakunya harga jual yang rendah. Di lain pihak, konsumen membutuhkan barang tersebut. Akibatnya, konsumen tidak terpuaskan harapan untuk memenuhi kebutuhannya karena keterbatasan penawaran.

Konsekuensi selanjutnya berlaku hukum permintaan dan penawaran yang menyebabkan harga naik. Dengan kenaikan harga ini, kedua belah pihak akan menderita. Penjual menderita karena mereka dibatasi menjual barang sesuai keinginannya dan pembeli juga menderita karena permintaannya tidak terpuaskan. Sementara penetapan harga melalui mekanisme pasar akan menciptakan kesenjangan yang semakin lebar antara mereka yang memiliki bargaining position yang kuat (umumnya mereka yang kaya) dengan yang lemah (umumnya mereka yang kurang mampu).

Mereka yang kaya akan mendapatkan harga yang murah melalui quantity discount, cash discount, dan berbagai potongan lainnya. Di lain pihak, mereka yang lemah akan membeli dengan harga normal tanpa mampu mendapatkan potongan harga. Dengan demikian terjadi ketidakadilan di dalam memperlakukan pembeli. Mereka yang kaya akan diperlakukan seperti raja yang mendapat perlakuan khusus dan pembeli yang lemah tingkat ekonominya tidak mendapat perhatian yang memadai (Alimuddin, 2011).

Dari segi penjual, harga yang terjadi di pasaran, bisa disebabkan karena persaingan murni dan bisa juga disebabkan karena persaingan semu. Untuk yang kedua ini, terjadi karena monopoli dan kartel sehingga harga yang terjadi di pasaran merupakan permainan sekelompok penjual dan pembeli hanya mengikutinya. Kondisi ini akan menciptakan 
ketidakadilan di dalam jual beli. Penjual akan mendapatkan keuntungan yang berlebih, sementara pembeli akan terzalimi dengan permainan harga yang dilakukan penjual (Alimuddin, 2011).

Menyadari akan kelemahan kedua cara penetapan harga jual tersebut, maka penjual dapat menetapkan sendiri harga jual dengan cara menjumlahkan seluruh biaya dan keuntungan yang diharapkan. Umumnya keuntungan yang diharapkan berbasis pada tingkat pengembalian investasi yang tentunya bertentangan dengan kaidah syariah, yaitu riba. Disamping itu, besarnya tingkat pengembalian investasi belum menjamin keadilan di dalam jual-beli.

Berdasarkan hal tersebut di atas, maka yang menjadi pokok permasalahan di dalam penelitian ini adalah bagaimana menentukan harga yang adil agar tercipta kemaslahatan umat manusia?.

Penelitian ini bertujuan untuk menemukan konsep penetapan harga jual berbasis nilai keadilan di dalam Islam.

Hasil penyusunan konsep penetapan harga jual tersebut, diharapkan dapat dirumuskan manfaat yang dapat diperoleh dari penetapan harga jual berbasis nilai keadilan di dalam Islam untuk kemaslahatan umat manusia.

\section{METODE PENELITIAN}

Metode yang digunakan dalam penelitian ini adalah metode yang telah lama dikembangkan di dalam dunia ilmu pengetahuan Islam, yaitu metode bayani, burhani, dan irfani (Abdullah, 2007). Metode bayani mengandalkan pada teks dari bacaan, kejadian, atau fenomena sedangkan metode burhani mengandalkan logika untuk memahami fenomena dan kejadian atau menafsirkan teks/bacaan. Sementara metode Irfani lebih mengandalkan intuisi untuk memperoleh ilmu pengetahuan. Ketiga metode ini akan digunakan secara terintegrasi.

\section{ANALISIS DAN PEMBAHASAN}

Pembahasan dalam penelitian ini didasarkan pada kajian atas al-Qur'an dan as-Sunnah serta pendapat cendekiawan muslim yang relevan dengan topik harga jual keadilan. Hasil kajian ini kemudian dikaitkan dengan paktik bisnis yang dilakukan pengusaha muslim di Indonesia sebagai pelengkap di dalam merumuskan konsep harga jual berbasis nilai keadilan di dalam Islam. Langkah-langkah pembahasan adalah sebagai berikut: 


\section{Konsep Keadilan Ekonomi Universal}

Menurut Rawls (1999), konsepsi keadilan bukan satu-satunya prasyarat bagi komunitas umat manusia tetapi harus mempertimbangkan kaitan yang lebih luas, yaitu bagaimana tujuan dan sasaran kerja sama sosial dikembangkan sehingga tidak terjadi konflik. Kendati keadilan hanya bagian dari konsepsi semacam ini tetapi merupakan bagian utama, yaitu menjadi kebajikan utama dari organisasi. Kebajikan tersebut berupa pemberian hak dan kewajiban serta pembagian keuntungan yang layak.

Lain halnya dengan pandangan (Kolm, 1995), keadilan ekonomi adalah pemenuhan kebutuhan dasar. Besarnya kebutuhan dasar ini berbeda di antara setiap orang, tergantung dari besarnya tanggungan yang diemban. Kebutuhan dasar bagi orang bujangan lebih rendah dari pada kebutuhan orang yang bekeluarga. Menurut Chris Sarlo (2009) yang telah mensurvei pengeluaran rumah tangga dengan mengatakan bahwa kebutuhan dasar manusia untuk bisa hidup layak, meliputi: food, shelter, clothing, health care, personal care, essential furnishings, transportation and communication, laundry, home insurance, education, and miscellaneous (http://en.wikipedia.org/wiki/ Basic_needs).

Sementara Hartropp (2010) lebih menitikberatkan pada keadilan di bidang ekonomi sebagai masalah sentral dalam dunia global sekarang ini. Untuk mengetahui adanya keadilan ekonomi pada suatu organisasi dapat dilihat pada tiga hal, yaitu hak (rights), kebutuhan (need), dan ganjaran (desert).

Gagasan tentang hak (rights) untuk sesuatu didasarkan pada asasi (inherent) dalam diri setiap umat manusia. Dalam pandangan Rawls (1999), keadilan semacam ini harus menggunakan prinsip kebebasan, dimana semua individu berhak mendapatkan hak dasarnya. Oleh karena itu, hak tidak memiliki hubungan konteks dengan seseorang tetapi merupakan sifat fundamental bagi setiap orang, maka, pandangan tentang keadilan ekonomi yang didasarkan pada konsep hak menyatakan bahwa keadilan itu didasarkan pada sesuatu yang asasi di dalam tiap-tiap manusia. Dengan demikian, menurut konsep hak ini, setiap orang berhak untuk mendapatkan kebutuhan dasar (misalnya air bersih, sandang, dan pangan) agar bisa hidup.

Sementara kebutuhan (needs) umat manusia, yaitu sesuatu yang dibutuhkan disesuaikan dengan konteks yang dihadapi. Kebutuhan masyarakat pantai akan berbeda dengan kebutuhan masyarakat pegunungan. Dengan demikian waktu dan tempat menjadi penentu jenis dan besarnya kebutuhan. Inilah yang menyebabkan perbedaan dengan keadilan yang didasarkan pada hak. Ganjaran (desert), dimaksudkan agar tercipta penghasilan yang wajar untuk pekerjaan yang dilaksanakan atau diselesaikan dengan baik (fair day's pay for a fair day's work), demikian juga halnya jika ada dua perusahaan yang secara bebas dan tanpa paksaan menyepakati sebuah harga tertentu untuk sebuah kontrak, maka hal tersebut dikatakan adil dan jika salah satu yang melanggar kontrak itu, maka ia dikatakan berlaku tidak adil (Hartropp, 2010). 
Dengan demikian, ada tiga cara yang berbeda untuk memahami keadilan ekonomi. Ketiganya memiliki kesamaan makna sampai pada taraf tertentu antara yang satu dengan yang lain tapi ketiganya berbeda secara jelas antara yang satu dengan yang lain dan bahkan bisa dikatakan memiliki pertentangan antara satu dengan lain. Ganjaran didasarkan pada kepantasan (merit), kebutuhan didasarkan pada konteks, dan hak didasarkan pada martabat sebagai manusia. Dari sini, dapat dilihat bahwa apa yang dimaksud dengan adil akan berbeda-beda, tergantung pada landasan apa yang digunakan. Jika upah didasarkan pada ganjaran, maka besarnya akan berbeda jika upah didasarkan pada kebutuhan individu. Dan jika upah didasarkan sepenuhnya pada hak, maka bisa dikatakan bahwa semua orang harus mendapatkan upah yang sama. Pendekatan keadilan mana yang akan digunakan?, tidak mungkin ada satu pendekatan yang paling benar sendiri (Hartropp, 2010) tergantung pada kondisi yang dihadapi.

Berkaitan dengan besarnya margin dari harga jual, maka pendekatan keadilan yang lebih relevan adalah perpaduan antara keadilan berdasarkan kebutuhan dan hak. Hal ini disebabkan karena setiap manusia memiliki hak untuk hidup layak dan itu berarti dia membutuhkan kebutuhan dasar bagi diri dan keluarganya. Besarnya kebutuhan dasar setiap umat manusia tergantung konteks yang dihadapi. Dengan demikian, besarnya margin penjualan dipengaruhi oleh besarnya kebutuhan dasar pedagang. Keadilan berdasarkan ganjaran (desert) lebih cocok diterapkan untuk menilai produktivitas dan kinerja keuangan yang murni kapitalis tanpa memperhatikan aspek lain dari suatu aktivitas.

Konsepsi keadilan yang dikemukakan di atas baru menyentuh tataran kebutuhan materi umat manusia di muka bumi ini, sedangkan kebutuhan umat manusia untuk menjalankan kewajibannya kepada Sang Pencipta-nya dan kebutuhan lingkungan di mana umat manusia beraktivitas belum menjadi perhatian untuk dimasukkan sebagai komponen keadilan.

\section{Konsep Keadilan Ekonomi dalam Pandangan Islam}

Secara hakiki, keadilan merupakan suatu konsep yang relatif. Skala keadilan tergantung pada tatanan sosial masyarakat pada suatu kelompok, apakah itu negara atau komunitas. Tidak menjadi masalah, bagaimana skala-skala tersebut berbeda satu sama lain, semua pada umumnya memiliki unsur-unsur tertentu dan secara luas dapat dibagi dalam dua kategori utama (Khadduri, 1984). Kategori pertama adalah keadilan positif yang bersumber dari kesepakatan atau persetujuan formal atau informal yang dibangun secara individu atau kolektif untuk membina atau menegakkan suatu tatanan publik yang mana suatu skala keadilan dapat dikembangkan. Dalam pandangan ini, keadilan ideal atau sempurna merupakan suatu hayalan belaka. Keadilan yang real berkembang melalui improvisasi dari generasi ke generasi berikutnya, setiap individu akan selalu berusaha untuk menyaring dan memajukannya melalui suatu proses perubahan sosial yang berkelanjutan. 
Oleh karena itu, manusia tidak hanya didorong untuk mengetahui dan memahami keadilan, akan tetapi juga berbuat sesuai dengannya. Di lain pihak, keadilan menurut alGhazali adalah menempatkan sesuatu pada tempat yang semestinya (Shihab, 2006), sedangkan al-Farabi dan Aristoteles, menganggap keadilan sebagai kebaikan tertinggi yang di dalamnya setiap kebaikan dimengerti Khadduri (dalam Mochtar dan Kahmar, 2001).

Dalam pandangan Islam, nilai keadilan terkandung makna menempatkan atau mendistribusikan/mendapatkan sesuatu sesuai dengan konteksnya (Shihab, 2006). Keadilan dalam berorganisasi apabila semua stakeholder merasakan perlakuan yang adil di antara mereka. Adalah tidak adil apabila ada sekelompok anggota steakholder mendapatkan perlakukan khusus dibandingkan dengan anggota kelompok lainnya. Misalnya, pemilik mendapatkan keuntungan berupa deviden yang jauh lebih besar daripada yang diterima pekerja berupa upah atau gaji. Demikian juga, penjual mendapatkan keuntungan yang lebih besar, sementara pembeli dibebani harga yang tinggi, dan perusahaan mendapatkan kemanfaatan yang besar dari lingkungan sementara mengabaikan keberlanjutannya (dirusak).

Itulah sebabnya di dalam ajaran Islam, prinsip keseimbangan di dalam segala sesuatu menjadi karakteristik utama bagi umatnya (Qardhawi, 2006). Islam menerapkan keseimbangan positif di dalam segala aspek, baik dalam aspek ideologi maupun praktis, materi maupun moril. Ia menyeimbangkan antara wahyu Tuhan dengan akal manusia, antara akal dengan hati, antara dunia dengan akhirat, antara fisik dan roh, serta antara hak dan kewajiban.

\section{Keadilan kepada Umat Manusia}

Dalam kaitannya dengan keseimbangan kebutuhan dunia dan akhirat, maka seorang Muslim harus berusaha untuk memenuhi kedua jenis kebutuhan tersebut sebagai tanda pengabdiannya. Untuk memenuhi kebutuhan akhirat berupa pelaksanaan rukun Islam (zakat dan haji), setidaknya dia harus terlebih dahulu memenuhi kebutuhan pokoknya di dunia. Setelah itu, barulah berusaha untuk meningkatkan pemenuhan kebutuhan untuk bekal tambahan ke akhirat (infak, sedekah, wakaf, dan qurban).

Pada sisi lain, Islam menegakkan keseimbangan antara individu dengan masyarakat tetapi tidak memberikan hak dan kebebasan kepada individu maupun masyarakat untuk berlaku sombong dan tidak memperhatikan kemaslahatan yang dapat menyebabkan kerusakan dan kehancuran. Dalam pandangan Qardhawi (2006), sesungguhnya manusia dilahirkan dalam keadaan merdeka sehingga tidak seorang pun yang boleh menghina dan menempatkan orang lain sebagai Tuhan, kecuali Allah. Oleh karena itu, setiap manusia mempunyai hak untuk hidup. Apabila ada manusia yang tidak mampu memenuhi kebutuhan hidupnya maka kewajiban manusia lainnya yang mampu untuk membantunya 
sebagai tanda kekhalifahannya, baik melalui bantuan langsung berupa zakat, infaq, sedekah, wakaf, maupun memberi kesempatan untuk berusaha sesuai kemampuannya.

Melalui cara ini akan tercipta keseimbangan dan pemerataan yang berkesinambungan yang bermuara pada suatu negeri yang baldatun thayyibatun wa rabbun qhafur - negeri yang baik, aman, dan sentosa buat semua penduduknya serta Tuhan melimpahkan anugerah-Nya (QS. as-Saba' [34]). Dan bukan menjadi masyarakat yang egois dan materialis, yang hanya mementingkan dirinya, tidak mau membantu sesamanya, dan tidak mau bersyukur seperti kaum Saba yang tidak mau berinteraksi dengan masyarakat dan negara lain karena takut akan berkurangnya kesejahteraan. Disamping itu, mereka tidak menginginkan kenikmatan yang selama ini dirasakan terbagi ke masyarakat lain (Shihab, 2006). Akibatnya, mereka mendapatkan balasan berupa kehancuran (QS. as-Saba' [34]), dan hilangnya kenikmatan yang dirasakan selama ini.

Demikian juga halnya, seorang pengusaha, bukan hanya memperhatikan perkembangan usahanya, tetapi juga perlu memperhatikan perkembangan masyarakat dan lingkungan alam di sekitarnya. Mencari keuntungan materi adalah perbuatan yang baik sepanjang dalam bingkai etika dan moral agama, tetapi mencari keuntungan dengan cara menzalimi sesama adalah perbuatan yang melanggar etika universal. Keuntungan yang baik adalah keuntungan yang memperhatikan keseimbangan antara kebutuhan penjual (Hartropp, 2010) dengan kemampuan pembeli secara umum. Dengan cara ini, perusahaan dan masyarakat akan bersatu padu menikmati kehidupan ini.

\section{Keadilan kepada Lingkungan}

Qardhawi (2000b) menyatakan bahwa krisis lingkungan yang kita hadapi sekarang adalah disebabkan karena manusia tidak lagi menyadari kepentingan bersama dari segala yang ada di alam semesta dan kesalingterkaitan antara semuanya itu. Selama manusia tidak menyadari bahwa semua mahluk memiliki hak yang sama untuk hidup di alam semesta dalam keseimbangan, maka tindakan-tindakan manusia akan menimbulkan kerusakan. Konsumerisme, obsesi akan laba (tanpa moralitas) telah membuat bangsa yang satu menghancurkan bangsa yang lain dan diri sendiri sehingga memunculkan sikap "tidak tahu berterima kasih terhadap ciptaan Allah” dan terhadap karunia Allah yang menyeimbangkan alam semesta (Al-Qaradawi, 2000b; Christie, 2004; dan Kamla et al., 2006). Bahkan Manzoor (2003), memandang bahwa krisis lingkungan yang terjadi dewasa ini adalah manifestasi yang paling menyolok dari peradaban Barat, dimana ilmu pengetahuan dan teknologi modern telah memberikan sumbangan yang besar untuk bisa merusak diri kita sendiri.

Seperti yang disampaikan Qardhawi (2000b), perlindungan, penjagaan dan perawatan terhadap lingkungan bukanlah sebuah konsep baru dan juga bukan konsep Barat, melainkan hal semacam itu berakar secara mendalam di semua bidang dari ajaran dan budaya Islam QS. al-Maa'idah [5]). Selanjutnya, Qaradawi (2000b) menjelaskan bahwa tidak diperbolehkan jika generasi yang satu memonopoli kemakmuran yang didapatkan 
dari alam dan ciptaan Tuhan dengan mengorbankan generasi masa depan. Prinsip Islam ini memiliki hubungan yang erat dengan konsep pembangunan berkesinambungan (sustainable development) (Asmal dan Asmal, 2007).

Memperhatikan masyarakat di sekitar perusahaan tidaklah cukup tanpa memberi perhatian yang sama terhadap lingkungan di mana perusahaan beroperasi. Lingkungan perlu mendapat perhatian yang serius karena dengan beroperasinya perusahaan tersebut akan menyebabkan lingkungan terganggu, pengrusakan, menimbulkan kecemburuan sosial akibat tidak tertampungnya semua tenaga kerja yang ada disekitar perusahaan, dan kemaslahatan umat secara keseluruhan. Oleh karena itu, perusahaan perlu berlaku adil dengan mengeluarkan sejumlah dana untuk memperbaiki lingkungan alam tersebut agar bisa berfungsi seperti sebelum adanya perusahaan beroperasi. Jika tidak mampu menyamainya, minimal mendekatinya.

Disamping itu, penduduk miskin di sekitar perusahaan yang tidak sempat bekerja pada perusahaan tersebut perlu mendapatkan kompensasi berupa santunan agar mereka bisa hidup layak. Hal ini sejalan dengan perintah agama bahwa apabila engkau memasak dan baunya tercium oleh tetanggamu maka seharusnya engkau memberikan sebagian kepadanya. Apabila kamu memasak kuah perbanyaklah airnya, lalu berikan sebagian kepada tetanggamu agar dengan itu kamu memperoleh kebaikan (HR. Muslim). Ini tidak berarti, bahwa ajaran ini mendorong seseorang untuk bermalas-malasan bekerja karena tetap juga mendapatkan bantuan atau kasih sayang. Tindakan ini dilakukan sebagai tanggungjawab kepada sesama yang telah berusaha untuk mendapatkan pekerjaan yang layak tetapi belum mendapatkan penghasilan yang memadai guna memenuhi kebutuhan pokoknya dan untuk menjalin hubungan kasih sayang di antara umat manusia.

Demikian juga halnya, seorang pengusaha muslim memiliki tanggungjawab atas kemaslahatan umat secara keseluruhan dengan membayar kewajiban berusaha kepada pemerintah di mana mereka berusaha. Dengan cara memperhatikan keseimbangan seperti ini, maka akan tercipta masyarakat yang rukun, aman, dan sejahtera, dan berkesinambungan. Pemeliharaan lingkungan, bukan hanya menjalin hubungan yang harmonis dengan umat manusia tetapi juga memelihara lingkungan alam dimana manusia beraktivitas. Hal ini penting agar tidak membebani permasalahan pada generasi berikutnya.

\section{Etika Pemenuhan Kebutuhan}

Islam melarang umatnya berbuat tidak adil dalam mencari harta terhadap orang lain tetapi mendukung penggunaan semua cara yang adil dan jujur dalam mendapatkan harta kekayaan. Hak individu untuk memiliki harta dan memanfaatkannya untuk kemaslahatan diri dan lingkungannya. 
Bahkan Kamla et al. (2006) mengungkapkan, Islam melarang pengejaran terhadap laba sampai berlebihan dan perilaku mencari laba yang menimbulkan kerugian atau bahaya bagi orang lain. Mendapatkan laba yang besar tetapi membiarkan kondisi kerja yang tidak sehat, upah yang tidak adil, menjual produk yang membahayakan umat, menimbulkan penyakit, merusak lingkungan, dan merusak tata nilai lokal yang tidak bertentangan dengan norma agama merupakan perbuatan yang egois dan materialis. Fazlun Khalid, seorang ekolog Muslim mengemukakan:

Sikap memuaskan hawa nafsu kita telah menyebabkan kita berkompetisi satu sama lain sebagai pengonsumsi, sebagai individu, dan sebagai negara, menyedot sumber daya bumi dengan kecepatan yang terus-menerus bertambah dan menghasilkan limbah dalam level yang tidak bisa didaur ulang oleh bumi. Dengan demikian, kita berkontribusi pada percepatan kerusakan pada habitat dan kehidupan orang-orang yang lemah. Kita merusak keseimbangan canggih alam. Kita membantai spesies-spesies lain hingga punah. Kita merampok hak generasi-generasi mendatang. Kita telah sedemikian terperangkap dalam pemuasan diri, hingga kita tidak menyadarinya (Asmal dan Asmal 2007).

Berkaitan dengan hal tersebut di atas, Kopontren Daarut Tauhiid dalam mengembangkan usahanya senantiasa memperhatikan lingkungannya dan bahkan kopontren ini ingin berkembang bersama masyarakat sekitarnya. Hal ini dapat diketahui dari pendapat yang dikemukakan oleh Hw, General Manager Cottage Daarul Jannah yang merupakan salah satu unit usaha kopontren ini.

Apabila ada tamu yang datang kesini bersilaturrahim atau mengikuti tausyiah dari Aa Gym dan mencari penginapan, kami memberikan informasi harga di cottage kami dan harga di beberapa penginapan disekitar kompleks yayasan Daarut Tauhiid dan bahkan kami sering menghubungi penginapan jika ada tamu yang meminta. Dan tidak jarang, tamu yang menginap di penginapan melalui bookingan kami, tetapi kami tidak mendapatkan sesenpun komisi atau pendapatan bahkan kami ikut memelihara kebersihan di sekitar penginapan tersebut. Salah satu tujuan keberadaan yayasan/kopontren ini adalah menyatu dengan lingkungannya, kalau kita bersih maka kami mengharapkan juga kebersihan tertular di lingkungan kami dan kalau kami berkembang maka kami mengharapkan penduduk atau usaha disekitar kami juga berkembang, kami tidak mau maju sendiri.

Pendapat tersebut di benarkan oleh GKK, Ketua Kopontren Daarut Tauhiid dan menambahkan;

Di sekitar SMM (Super Mini Market), salah satu unit usaha kopontren Daarut Tauhiid, terdapat banyak pedagang kaki lima (pakaian, makanan dan minuman jadi, buku, warung, dan lain sebagainya) di dalam kompleks ini yang berjualan dan kami tidak pernah melarangnya walaupun mereka adalah pesaing kami. Cita-cita kami adalah ingin maju bersama. Mereka butuh pekerjaan untuk menghidupi keluarganya kami juga demikian. Bersyukurlah mereka bisa bekerja mandiri. . . dengan adanya sinergi ini mendorong kami untuk bekerja lebih efisien dan ujung-ujungnya yang merasakan adalah pelanggan karena bisa membeli dengan harga yang relatif murah dan kami juga bisa eksis. 
Demikianlah pengusaha muslim mencari penghidupan dengan senantiasa menjunjung tinggi keseimbangan antara kebutuhannya dengan kebutuhan karyawan dan masyarakat sekitarnya, antara efisiensi dengan pemeliharaan lingkungan, dan antara sifat egoistik dan materialistik dengan altruistik. Dan bukan menjadikannya sebagai mutually exclusive, bahkan mereka hidup berdampingan meraih keberhasilan bersama.

Dalam pandangan Islam, kepemilikan individual sangat dijunjung tinggi karena selain sesuai dengan naluri alamiah manusia, juga merupakan syarat mutlak bagi pemurnian diri atau perkembangan kepribadian manusia. Meskipun Islam membolehkan kepemilikan pribadi dalam batas-batas yang alami dan wajar tetapi tidak menghendaki adanya kesenjangan yang lebar antara yang kaya dengan yang miskin. Islam sangat melarang umatnya hidup bermewah-mewahan sementara sebagian yang lain hidup dengan kekurangan dan kelaparan. Itulah sebabnya sehingga dibutuhkan zakat, infak, sedekah, dan wakaf (ZISW) guna menjamin pemerataan ekonomi, khususnya kepada mereka yang kurang mampu dan mensucikan harta muzakki (pembayar ZISW). Dengan demikian, ZISW akan menyeimbangkan sifat egoistik dengan sifat altruistik, mengembangkan nilai emansipatoris untuk membebaskan manusia dari ketertindasan ekonomi, sosial, intelektual, dan pembebasan alam dari eksploitasi manusia (Triyuwono, 2006b).

Perbedaan kekayaan tidak boleh melampaui batas-batas yang alamiah dan masuk akal sehingga memunculkan hidup bermewah-mewahan. Perbedaan ini akan menimbulkan kebencian dan permusuhan yang membawa pada suatu konflik kekerasan di antara berbagai lapisan masyarakat yang pada akhirnya akan menghancurkan fondasi kehidupan (QS. al-Israa' [17] dan at-Takatsur [102]), tetapi tidak berarti Islam memaksakan umatnya untuk membagikan harta orang kaya kepada orang miskin agar diperoleh pemerataan ekonomi. Keadilan ekonomi dalam pandangan Islam adalah adanya keadilan bagi semua orang untuk mencari kekayaan dan tidak dibatasi oleh kasta-kasta, warna kulit, agama, suku bangsa, dan lain sebagainya (Afzalurrahman, 1982).

Bagaimanapun Islam tidak mendukung ketidakmerataan tetapi juga tidak mengajarkan pemerataan kekayaan. Bagi Islam, ketidakmerataan kekayaan bisa dimanfaatkan untuk meningkatkan hubungan manusia dengan Penciptanya dan hubungan manusia dengan manusia lainnya sehingga terjadi keseimbangan. Orang yang kekurangan akan belajar untuk bersabar, toleran, dan puas hati. Sementara orang yang berada dapat mengembangkan potensi baiknya dengan berkorban untuk kebajikan sehingga akan tercipta hubungan yang saling membutuhkan. Dengan demikian semua akan mendapat berkah dari ketidakmerataan ini.

Berdasarkan penjelasan dan analisis tersebut di atas, maka etika pemenuhan ekonomi yang Islami di dalam berusaha dalam perspektif bayani adalah pemenuhan kebutuhan dunia, baik untuk diri sendiri pengusaha, maupun untuk mitra bisnis termasuk mereka yang memiliki keterbatasan fisik, mental, dan fikiran. Pemenuhan kebutuhan dunia ini 
dimaksudkan agar setiap umat manusia bisa hidup mandiri dan tidak tergantung dengan belas kasihan. Hal ini sejalan dengan praktik bisnis yang diterapkan Yayasan dan Kopontren Daarut Tauhiid di Bandung seperti yang dijelaskan di atas.

Sementara dalam perspektif burhani, etika pemenuhan ekonomi di dalam berusaha, tidak hanya untuk memenuhi kebutuhan hidup umat manusia di dalam beraktivitas tetapi mereka juga harus bisa memenuhi kebutuhan akhiratnya. Kebutuhan yang terakhir ini dimaksudkan untuk investasi akhirat yang akan bisa dinikmati di kehidupan yang kekal. Dengan demikian tercipta keseimbangan hidup antara kehidupan dunia (profan) dengan kehidupan akhirat.

Dalam perspektif irfani, konsep etika pemenuhan ekonomi di dalam berusaha tidak hanya sebatas pemenuhan kebutuhan pokok pengusaha tetapi yang tidak kalah pentingnya adalah menjalin hubungan yang berkelanjutan dengan generasi yang akan datang dan menjalin hubungan yang lebih harmonis dengan masyarakat sekitarnya.

\section{Keuntungan Berbasis Keadilan}

Di dalam Islam, tidak ada batasan tentang besarnya jumlah keuntungan (Omar et al., 2010), hal ini didasarkan pada hadits Bukhari yang mengisahkan seorang sahabat Nabi, yaitu Urwah yang membeli 2 ekor kambing dengan harga 1 dirham dan menjual 1 ekor dengan harga 1 dirham dan Nabi Muhammad tidak melarangnya. Bahkan, Zubayr ibn Awwam membeli sebidang tanah dengan harga 170.000 dinar dan beberapa waktu kemudian dia menjualnya dengan harga 1.600 .000 dinar.

Taimiyah sendiri mengakui perlunya keuntungan dalam jual beli. Karena itu, harga yang terjadi sudah termasuk di dalamnya keuntungan. Menurutnya, Keuntungan yang adil adalah keuntungan yang setara, yaitu keuntungan normal yang secara umum diperoleh dari jual beli tanpa ada yang dirugikan. Ia tidak menyetujui keuntungan yang sifatnya menzalimi atau eksploitatif (ghaban fahish), termasuk memperoleh keuntungan yang lebih besar dari keuntungan normal atas permintaan suatu produk yang sangat dibutuhkan dan mendesak, misalnya makanan dan minuman tertentu. Pendapat ini sejalan dengan yang diperintahkan Rasulullah saw bahwa menjual barang kebutuhan pokok kepada seseorang yang sangat membutuhkannya dengan menetapkan keuntungan yang melebihi keuntungan normal merupakan perbuatan zalim dan sangat dilarang (Islahi, 1997).

Meskipun demikian, Taimiyah belum mampu mengoperasionalkan makna keuntungan setara. Dia hanya mengambil perbandingan dengan harga jual umum. Persoalannya, jika harga jual umum yang berlaku ternyata menzalimi orang lain (pembeli), misalnya pada pasar oligopoli, apakah ini dapat dikatakan sebagai keuntungan yang serata atau adil. Demikian juga halnya, kesulitan penerapan besarnya keuntungan setara, jika produk yang dihasilkan adalah produk baru yang belum ada di pasaran. Ini berarti belum ada harga jual normal yang berlaku. 
Sementara Qardhawi (2000a), memiliki pendapat yang lebih operasional tentang seberapa besar perusahaan menetapkan keuntungan dari hasil penjualannya dengan mengacu pada syariah Islam. Di dalam syariah Islam, penjual dilarang berdagang tanpa memperoleh keuntungan dalam satu periode yang diakibatkan oleh penetapan harga di bawah atau sama dengan jumlah biaya. Pendapat ini didasarkan pada hadits (HR Imam Tirmidzi dari Amir bin Syu'aib, Nabi saw bersabda "Ingatlah, siapa yang mengurus anak yatim, sedangkan anak itu mempunyai harta, maka hendaklah ia memperdagangkannya, dan jangan dibiarkan dimakan zakat”) yang maknanya, harta tersebut harus berkembang-biak dan dalam kaitan dengan penjualan maka penetapan harga jual harus melebihi jumlah biayanya. Ini juga menunjukkan bahwa Islam tidak mengenal penimbunan barang dan menganjurkan produktivitas pemanfaatan harta.

Berapa besar minimal laba yang dapat dipetik dari penjualan tersebut, oleh Qardhawi (2000b) ditetapkan sebesar jumlah zakat yang akan dibayarkan atas harta tersebut ditambah dengan kebutuhan nafkah pemiliknya beserta keluarganya (yang menjadi tanggungannya). Penambahan kebutuhan nafkah dalam penetapan harga jual minimal untuk menghindari berkurangnya harta tersebut dikemudian hari. Kebutuhan nafkah (dasar) tersebut meliputi kebutuhan makan, air, sandang, papan, berumah tangga, pendidikan, kesehatan, tabungan haji dan umrah (Qardhawi, 2000).

Duns Scotus berpendapat bahwa keuntungan yang adil adalah keuntungan yang dapat memenuhi kebutuhan keluarga secara layak (Islahi, 1997). Dia tidak mampu mengoperasionalkan apa-apa saja yang termasuk kebutuhan keluarga yang layak. Ukuran layak pun dipertanyakan kriterianya, tetapi Chris Sarlo, mencoba memberikan jalan keluar atas kebutuhan layak seperti disebutkan di atas. Kebutuhan ini hanya didasarkan pada kebutuhan diri sendiri di dunia, belum memasukkan kebutuhan akhirat dan kebutuhan lingkungan.

Dalam pandangan peneliti, keuntungan yang adil, bukan hanya memperhatikan kemampuan pembeli secara umum serta kebutuhan hidup (kebutuhan makan, air, sandang, perumahan, pendidikan, kesehatan, transportasi dan komunikasi, keamanan, dan berumahtangga) dan akhirat penjual tetapi yang tak kalah pentingnya adalah melakukan perbaikan dan menjalin hubungan yang harmonis dengan lingkungan sekitar dimana usaha beroperasi. Memasukkan unsur lingkungan dalam komponen keuntungan dimaksudkan mengembalikan fungsi lingkungan seperti sebelum terjadinya kerusakan akibat beroperasinya perusahaan tersebut dan menjalin hubungan yang harmonis dengan masyarakat sekitarnya dengan memberikan santunan kepada mereka yang tidak mampu.

Dengan memasukkan ketiga unsur tersebut di atas dalam menentukan besarnya keuntungan, yaitu kemampuan pelanggan secara umum, kebutuhan pengusaha, dan pemeliharaan lingkungan di mana perusahaan beraktivitas sebagai komponen margin keuntungan akan menciptakan pembangunan yang berkesinambungan. Hal ini terjadi 
karena pertama, perusahaan menciptakan hubungan yang harmonis bukan hanya dengan manusia disekitarnya (pembeli dan masyarakat yang kurang mampu), dengan Penciptanya, tetapi juga dengan lingkungan alam sekitarnya. Kedua, menciptakan perpaduan antara sifat egoistik dengan sifat altruistik dan lingkungan alam di sekitarnya (Kamla et al., 2006). Ketiga, akibat perpaduan sifat egoistik dan altruistik akan berdampak pada hubungan kerja di dalam perusahaan yang tidak hanya mementingkan diri sendiri tetapi juga menjalin hubungan yang harmonis dengan sesama karyawan, manajemen, pemilik, dan dengan Sang Penciptanya, serta memelihara sumber daya yang dimiliki. Melalui pendekatan ini, para karyawan akan bekerja secara tulus untuk meningkatkan efisiensi dan kualitas produk yang dihasilkan karena mereka merasa menyatu bukan hanya perusahaan dengan pelanggan tetapi juga dengan lingkungannya. Keempat, dengan melakukan pemeliharaan lingkungan alam akan menciptakan hubungan yang berkesinambungan antara generasi sekarang dengan generasi yang akan datang (Kamla et al., 2006; Asmal dan Asmal, 2007). Kelima, dengan mengciptakan hubungan yang harmonis dengan sesama manusia, lingkungan alam, dan Sang Pencipta membentuk keasadaran ontologis kepada setiap umat manusia, minimal pelaku bisnis bahwa segala bentuk aktivitasnya bukan hanya bersifat profan tetapi dia juga sudah mempersiapkan pertanggungjawabannya di hadapan Allah swt di akhirat kelak sebagai pengemban amanah.

Dengan demikian dapat disimpulkan bahwa, keuntungan yang adil dalam perspektif bayani adalah sebesar kebutuhan dasar pedagang agar bisa bertahan hidup di muka bumi ini. Kebutuhan tersebut meliputi kebutuhan makan, air, sandang, perumahan, pendidikan, kesehatan, transportasi dan komunikasi, keamanan, dan berumahtangga. Sementara dalam perspektif burhani, besarnya keuntungan didasarkan pada besarnya kebutuhan hidup (seperti pada perspektif bayani) dan kebutuhan akhirat, berupa kewajiban menjalankan rukun Islam dan sunnah untuk kepentingan diri sendiri, yaitu haji, umrah, dan qurban, sedangkan besarnya keuntungan yang adil dalam perspektif irfani adalah sebesar kebutuhan hidup dan kebutuhan akhirat pribadi pedagang (seperti pada perspektif burhani) dan kebutuhan hubungan dengan lingkungan, yaitu lingkungan umat manusia dimana pedagang/perusahaan beraktivitas (meliputi kebutuhan infaq, sedekah, wakaf, dan bantuan lainnya untuk meningkatkan martabat umat manusia disekitar tempat usaha) dan hubungan dengan lingkungan alam, berupa pemeliharaan lingkungan alam agar bisa berfungsi seperti sebelumnya.

\section{Perubahan Harga Berbasis Keadilan}

Taimiyah mendukung perubahan harga yang disebabkan oleh perubahan permintaan dan penawaran sepanjang hal tersebut tidak dikendalikan oleh kepentingan seseorang atau kelompok dan tidak adanya faktor kecurangan untuk mengendalikan harga (Islahi, 1997: 104-6). Kenaikan dan penurunan harga yang dilakukan dengan keadilan, maka hal tersebut adalah sah. Meningkatnya permintaan atas suatu produk akibat bertambahnya penduduk sehingga menyebabkan harga naik sebaliknya terjadi kenaikan penyediaan 
produk sementara permintaan tidak meningkat (konstan) akan menyebabkan penurunan harga. Kenaikan dan penurunan harga tersebut sepanjang tidak dilakukan dengan kezaliman, maka kenaikan dan penurunan harga tersebut dibenarkan.

Perubahan harga jual tersebut sejalan dengan pemikiran Gambling dan Karim (1991) serta Baydoun dan Willet (1994) yang menggunakan current cost accounting untuk menentukan besarnya nilai asset dalam menghitung besarnya kewajiban zakat. Itu mengindikasikan bahwa penetapan harga jual selayaknya mengikuti juga perubahan harga yang terjadi di pasar, tidak perlu menunggu perubahan harga masukan karena nilai dari produk tersebut telah mengalami perubahan.

Dalam pandangan peneliti, kenaikan harga, baik yang diakibatkan oleh kezaliman penjual atau pembeli maupun karena meningkatnya permintaan secara alamiah seharusnya tidak diikuti oleh kenaikan harga sepanjang produk tersebut berasal dari persediaan sebelum terjadinya peningkatan permintaan (belum mengalami kenaikan biaya masukan). Pertimbangannya, pertama adalah tidak ada kenaikan input (biaya produksi). Produk yang diperdagangkan tersebut tidak mengalami kenaikan harga satuan masukan. Hal ini sejalan dengan metode penetapan harga jual cost-plus pricing (Kotler dan Armstrong, 1997). Kedua, adalah niat. Sesungguhnya amal ibadah itu ditentukan oleh niatnya, jika niatnya untuk menjual produk tersebut telah ditetapkan sesuai dengan harga jual yang berlaku selama ini maka seharusnya harga jual tersebut tidak perlu dinaikkan meskipun harga dipasaran telah mengalami kenaikan. Hal ini sejalan dengan kisah Yunus bin Ubid menunjukkan bahwa meskipun petugas penjualnya (pramuniaga) telah melakukan penetapan harga jual melebihi ketentuan/niat harga jual yang telah Yunus tetapkan dan pembeli menyetujui/ridha terhadap harga tersebut tetapi Yunus tidak menyetujui penjualan tersebut terjadi karena tidak mau melakukan pengingkaran terhadap niatnya (harga yang sudah ditetapkan sebelumnya). Ketiga, perubahan harga jual akan mendorong terciptanya perbuatan spekulasi dan inefisiensi dalam berusaha dengan membeli stock barang yang banyak dengan harapan akan mendapatkan kenaikan keuntungan di masa yang akan datang melalui perubahan harga.

Akan tetapi jika pengadaan barang tersebut mengalami kenaikan biaya masukan, maka harga jualnya akan disesuaikan, sebagaimana penerapan metode cost-plus pricing konvensional. Hal ini disebabkan karena harga pokok barang tersebut mengalami peningkatan sehingga apabila harga jualnya tidak dinaikkan maka ada kemungkinan penjual akan dirugikan. Sebaliknya, apabila harga jual tidak dinaikkan, maka penjual akan menahan produknya dan akan mengakibatkan kelangkaan barang di pasaran sehingga akan menyebabkan terjadinya kerusakan harga dan rusaknya kesejahteraan masyarakat.

Sebaliknya, jika terjadi kenaikan harga akibat ulah manusia, misalnya dengan menimbun barang yang mengakibatkan persediaan barang dipasaran mengalami kelangkaan yang 
menyebabkan harga jual meningkat. Kenaikan harga seperti ini tidak diperkenankan karena hanya menguntungkan seseorang dan merugikan pihak lain (masyarakat). Demikian juga halnya dengan kenaikan permintaan yang bersifat insidentil, misalnya karena bencana alam maka tidak diperkenankan menaikkan harga jual dengan memanfaatkan ketidakberdayaan pelanggan.

\section{Konsep Harga Jual Islami Berbasis Keadilan}

Dalam pandangan Islam, pemerintah tidak dibenarkan memihak kepada pembeli dengan mematok harga yang paling tinggi (celling price) atau memihak kepada penjual dengan mematok harga yang paling rendah (floor price). Namun perusahaan sering kali berusaha untuk mengalahkan pesaingnya dengan membangun monopoli atau kartel (Mathis, 2009), penimbunan, dan kecurangan atau permainan terhadap kebutuhan manusia sehingga penetapan harga produk perlu dan bahkan wajib dilakukan oleh otoritas pemerintah. Jadi prinsipnya, sepanjang kenaikan harga tersebut terjadi secara normal maka pemerintah tidak boleh campur tangan tetapi apabila sudah terdapat kezaliman di dalamnya maka pemerintah wajib melindungi masyarakat secara umum dengan menetapkan harga. Menurut Mathis (2009), negara memiliki kewenangan yang bisa mengendalikan kartel sehingga bisa menjalankan peran korektif di sini. Ini akan memberikan efek yang diinginkan tidak hanya bagi efisiensi tapi juga bagi distribusi kepada konsumen dengan lebih murah.

Berkaitan dengan hal tersebut, Islam menawarkan penetapan harga jual berkeadilan dengan mempertimbangkan kemampuan dan kebutuhan pembeli dan penjual. Kemampuan pembeli yang menjadi fokus perhatian adalah daya beli masyarakat secara umum. Tidak ada gunanya menetapkan harga jual yang tinggi dengan harapan mendapatkan keuntungan yang besar sementara masyarakat tidak memiliki kemampuan untuk membelinya. Demikian juga sebaliknya, menetapkan harga jual yang rendah dengan keuntungan yang rendah pula sementara masyarakat memiliki daya beli yang tinggi akan menciptakan ketidakmampuan penjual untuk memenuhi kebutuhan hidupnya. Untuk itu perlu ditetapkan harga yang adil untuk kedua belah pihak tersebut.

Pemilihan kebutuhan sebagai dasar penentuan besarnya keuntungan didasarkan pada pemahaman bahwa kebutuhan adalah sebuah liabilitas/tanggungan bagi manusia, yang sifatnya simetris dengan aset manusia yang terbentuk dari kapasitas yang dimiliki manusia, terutama kapasitas produktif. Kebutuhan dari seorang manusia juga adalah sesuatu yang ia terima apa adanya (given) dan bukan ia pilih sendiri. Karenanya, pertimbangan-pertimbangan tentang pemenuhan kebutuhan individu yang menyatakan bahwa pemerataan harus terwujud akan berujung pada ide bahwa beban manusia harus ditanggung secara bersama. Akibatnya, "tiap orang memberikan sesuai kemampuannya, dan tiap orang menerima sesuai kebutuhannya” (Blanqui dalam Hartropp, 2010). Dari berbagai jenis kebutuhan yang ada, kebutuhan dasar adalah yang paling penting karena diperlukan bagi eksistensi dari manusia dalam konteks sosialnya dan hubungannya 
dengan Penciptanya. Oleh karena itu kebutuhan dasar ini sebagian besar adalah kebutuhan untuk menjaga martabat.

Kebutuhan dasar tersebut seharusnya meliputi kebutuhan dunia agar bisa eksis mempertahankan kehidupannya dan kebutuhan akhirat agar bisa menikmati indahnya kehidupan yang kekal, sedangkan untuk menjamin kehidupan umat manusia di dunia ini, sebagai mahluk sosial, maka mereka membutuhkan hubungan dengan lingkungannya, baik dengan sesamanya maupun dengan lingkungan alam dimana mereka berada.

Dengan demikian penentuan besarnya harga jual berkeadilan dalam perspektif bayani adalah cost-plus profane basic needs, yaitu penetapan harga jual yang didasarkan harga masukan (jumlah biaya) ditambah keuntungan yang adil. Hal ini sejalan dengan hakikat pengembang-biakan harta (HR Tirmidzi) dan sejalan dengan prinsip umum berusaha yang senantiasa mengharapkan keuntungan.

Keuntungan yang adil adalah keuntungan yang tidak merugikan umat manusia. Meraup keuntungan yang besar atau sangat kecil bahkan tidak ada keuntungan merupakan perbuatan zalim. Keuntungan yang adil adalah keuntungan yang mempertimbangkan kemampuan calon pembeli secara umum dengan keuntungan yang diharapkan pemilik usaha. Keuntungan yang diharapkan meliputi kebutuhan hidup pemilik dan keluarganya (profan). Kebutuhan hidup pemilik menurut Qardhawi (2000) meliputi kebutuhan makan, air, sandang, papan, berumah tangga, pendidikan, dan kesehatan.

Dalam pandangan peneliti, kebutuhan hidup tersebut setidaknya meliputi: kebutuhan makan, air, sandang, perumahan, pendidikan, kesehatan, transportasi dan komunikasi, keamanan, dan berumahtangga. Kebutuhan makan didasarkan pada hadits Nabi yang mengatakan "sesungguhnya badanmu mempunyai hak atas kamu". Oleh karena itu kebutuhan makanan harus bisa memenuhi standar empat sehat lima sempurna. Kebutuhan air guna memenuhi keperluan minum dan membersihkan badan pada umumnya serta berwudhu sebagai syarat untuk melaksanakan shalat. Kebutuhan sandang dimaksudkan untuk menutupi aurat (QS. al-A'raaf [7]) dan pakaian untuk menghadiri peristiwa tertentu, seperti pakaian untuk shalat Jumat dan Ied, sedangkan kebutuhan perumahan harus memenuhi ciri kediaman yang asri, seperti layak huni, luas dan lapang sehingga terpisah kamar antara orang tua dengan anak-anaknya dan antara anak perempuan dengan anak laki-laki ditambah kamar tidur untuk tamu yang sewaktu-waktu terpaksa menginap (HR Muslim dan Jabir), penghuni rumah tidak kelihatan oleh orang yang lalu lalang di depannya, dan memiliki prabot yang layak.

Demikian juga halnya dengan kebutuhan pendidikan bagi seluruh keluarga. Pendidikan tersebut harus bisa meningkatkan kemampuan kepala keluarga agar tidak ketinggalan perkembangan ilmu pengetahuan, pendidikan untuk pengelolaan rumah tangga bagi istri, dan pendidikan untuk anak-anak yang bisa mengangkat harkatnya dikemudian hari. 
Sementara kebutuhan kesehatan harus bisa menjamin jika salah seorang anggota keluarga menderita sakit atau akan melakukan pemeriksaan berkala mendapat perawatan/ pelayanan yang layak, sedangkan kebutuhan transportasi dan komunikasi menjadi kebutuhan akibat perkembangan zaman. Kebutuhan transportasi untuk mengangkut anggota keluarga dengan aman dan tidak memperlihatkan aurat, sementara kebutuhan komunikasi berupa fix phone dan phone cell agar anggota keluarga dapat berhubungan dengan baik tanpa hambatan jarak.

Adapun kebutuhan keamanan dimaksudkan agar anggota keluarga dapat menjalankan aktivitasnya dengan aman, misalnya pengamanan rumah tangga, pengamanan di dalam perjalanan. Sementara kebutuhan berumatangga diperuntukkan bagi pribadi bujang (HR Muslim, Ahmad, dan Nasa'i. Mereka harus mempersiapkan diri untuk berumahtangga melalui menabung untuk biaya pernikahan dan pesta pernikahan secara layak.

Sementara dalam pemahaman burhani, harga jual berbasis keadilan adalah harga jual yang didasarkan pada jumlah biaya ditambah keuntungan yang adil. Keuntungan yang adil adalah keuntungan yang cukup untuk memenuhi kebutuhan pokok pemilik usaha dan keluarganya, yaitu kebutuhan dunia (seperti dijelaskan di dalam perspektif bayani di atas) dan kebutuhan untuk bekal ke akhirat. Jenis kebutuhan akhirat meliputi kebutuhan untuk melaksanakan rukun Islam, yaitu haji dan zakat dan sunnah, yaitu, umrah, dan qurban. Dengan demikian, harga jual berbasis keadilan adalah cost-plus basic needs.

Dalam metode irfani, penetapan harga jual berbasis keadilan adalah cost-plus basic needs and environment, yaitu penetapan harga yang menyeimbangkan antara kebutuhan dunia (profan) dengan kebutuhan akhirat, antara kebutuhan diri sendiri dan kemampuan pembeli, antara kebutuhan diri sendiri dengan masyarakat sekitarnya, dan antara kebutuhan diri sendiri dengan lingkungan sekitarnya, sebagaimana telah dijelaskan pada keseimbangan hidup sebelumnya. Dengan demikian, penetapan harga keadilan menurut metode irfani diharapkan tidak akan menzalimi diri sendiri, orang lain, dan lingkungan di mana perusahaan beroperasi. Penambahan unsur lingkungan dalam salah satu komponen keuntungan dimaksudkan untuk menciptakan pelestarian lingkungan alam yang telah dirusak dan menjalin hubungan yang harmonis dengan masyarakat sekitarnya dan generasi yang akan datang. Secara umum, konsep harga jual berbasis nilai keadilan di dalam Islam dapat di lihat pada gambar 1.

Kepedulian terhadap orang lain adalah bagian integral dari visi dan praktek di dalam menjaga lingkungan sesuai dengan ajaran Islam, karena manusia sendiri adalah bagian dari lingkungan. Ini juga merupakan sikap egalitarian dan hakikat hidup berkomunitas (Umma) yang menentang sikap egois dan individualis karena melanggar martabat manusia dan moralitas (Hartropp, 2010 dan Kolm, 1995). Saling berbagi adalah lebih diutamakan daripada perilaku individu yang berfoya-foya (Nash, 2007) yang dipandang sebagai kerusakan moral. Dalam hal ini, Islam melarang perilaku yang menimbulkan 
pemborosan dan keserakahan (Kamla et al. 2006) dengan hanya mementingkan diri sendiri. Pencipta Bumi ini sangat menganjurkan hidup saling menolong kepada siapa saja, sebagaimana firmannya: "dan tiadalah binatang-binatang yang ada di bumi dan burung yang terbang dengan kedua sayapnya, melainkan umat seperti kamu juga” (QS. al-An’aam [6]) dan Rasulullah bersabda, barang siapa meringankan kesulitan seorang di dunia, niscaya Allah akan meringankan kesulitannya di dunia dan di akhirat (HR. Abu Hurairah).

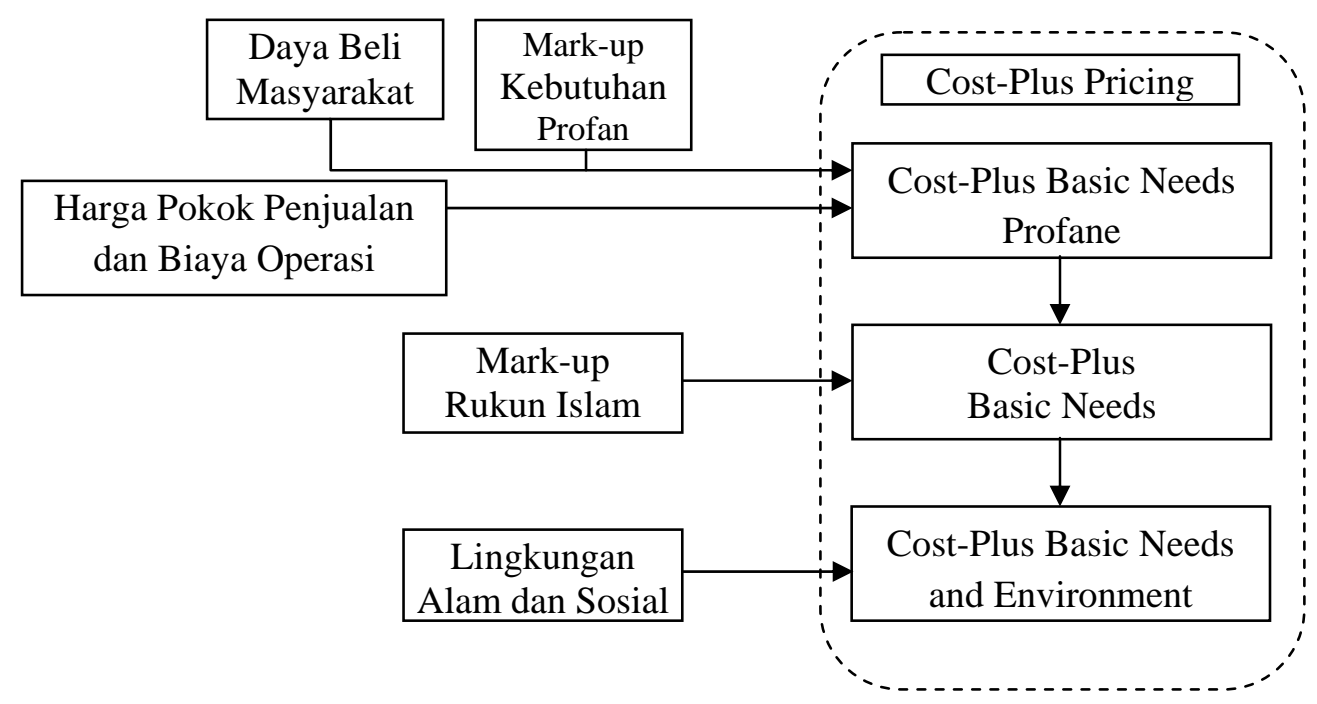

\section{Gambar 1}

Konsep Harga Jual Berbasis Nilai Keadilan

Mengambil keuntungan yang hanya untuk memenuhi kebutuhan dasar dan pemeliharaan lingkungan merupakan perbuatan yang egalitarian, yang tidak hanya mementingkan diri sendiri. Dengan demikian, penetapan harga jual menurut metode irfani meliputi seluruh biaya ditambah kebutuhan dunia dan akhirat serta kebutuhan untuk menjaga kelestarian alam dan menjaga hubungan harmonis dengan masyarakat disekitar tempat usaha. Kebutuhan untuk menjaga pelestarian alam adalah untuk mengembalikan fungsi alam seperti sebelum terjadi pengrusakan akibat pengolahan yang dilakukan dan kebutuhan untuk menjalin hubungan yang harmonis dengan masyarakat melalui infak, sedekah, wakaf, dan bantuan lainnya yang dapat meningkatkan taraf hidup masyarakat disekitar dimana perusahaan beroperasi.

Berdasarkan analisis tersebut di atas, maka secara umum konsep harga jual berbasis nilai keadilan adalah cost-plus pricing, yaitu suatu konsep harga jual yang memperhitungkan seluruh biaya yang terjadi untuk menghasilkan produk hingga sampai ke tangan pembeli ditambah kebutuhan pokok pedagang dan untuk pelestarian lingkungan. Sekilas, konsep 
harga jual ini sama dengan konsep penetapan harga jual cost-plus pricing pada paham konvensional, yaitu biaya ditambah keuntungan yang diharapkan. Perbedaannya terletak pada makna keuntungan dan penentuan besarnya keuntungan.

Pada konsep harga jual berbasis nilai keadilan, keuntungan dimaknai sebagai pemenuhan kebutuhan pokok penjual dan untuk menciptakan keseimbangan hidup dengan pelanggan dan lingkungan di sekitar di mana perusahaan beroperasi, sedangkan besarnya keuntungan yang diharapkan dipengaruhi oleh besarnya kebutuhan pokok penjual dan biaya pelestarian lingkungan serta kemampuan pembeli. Dengan demikian, konsep harga jual ini memperhatikan kemaslahatan hidup untuk memenuhi kebutuhan individu penjual dengan kolektif, yaitu pemenuhan kebutuhan diri sendiri, kebutuhan antara sesama umat manusia dan antara umat manusia dengan lingkungannya, kemaslahatan ukhrawi dengan menjalankan rukun Islam. Dengan demikian keuntungan yang ada bukan hanya berwujud materi (profan) tetapi menjalin hubungan yang harmonis diantara sesama umat manusia dan lingkungan serta menjadi bekal di akhirat kelak berupa investasi akhirat. Akibatnya, kinerja yang didapatkan lebih variatif dan lebih besar daripada mendapatkan keuntungan yang sifatnya egoistik dan materialistik (Alimuddin, 2010). Usaha yang demikian inilah yang bertahan hidup dan berkembang.

Pada konsep harga jual konvensional, keuntungan yang diharapkan (return) dari penjualan produk, umumnya didasarkan pada tingkat bunga yang berlaku umum ditambah risiko (Kotler dan Armstrong, 1997). Artinya keuntungan tersebut dipengaruhi oleh pihak eksternal, yaitu tingkat bunga yang berlaku umum dan risiko di dalam berusaha, bukan kebutuhan murni penjual. Demikian juga halnya dengan penentuan besarnya keuntungan yang diharapkan sangat dipengaruhi oleh kondisi ekonomi dan situasi politik suatu negara. Apabila kondisi ekonomi baik dan situasi politik yang kondusif, maka akan berdampak pada tingkat bunga dan tingkat risiko berusaha yang relatif rendah. Demikian juga sebaliknya. Oleh karena tingkat bunga pinjaman mempengaruhi besarnya keuntungan yang diharapkan, maka komposisi sumber dana yang digunakan akan berkontribusi langsung di dalam penentuan besarnya keuntungan yang diharapkan. Semakin besar sumber dana eksternal, semakin besar pula beban bunga yang harus ditanggung. Demikian juga sebaliknya. Ini menunjukkan bahwa besarkecilnya keuntungan yang diharapkan sangat dipengaruhi oleh kondisi eksternal perusahaan yang cenderung tidak dapat dikendalikan. Menurut Schumacher (1987) di sinilah terjadi ketidakadilan dan juga tidak masuk akal karena pemilik modal yang tak berfungsi tetapi bisa hidup sebagai parasit atas usaha orang lain. Oleh karena itu keuntungan harus bisa dinikmati semua pemangku kepentingan (Schumacher, 1987; Hill dan Jones, 1992) agar tercipta keadilan di dalam berusaha.

Ketidakadilan penetapan harga jual juga bisa terjadi karena keuntungan yang diperoleh tidak cukup untuk memenuhi kebutuhan pengusaha dan keluarganya, baik kebutuhan di dunia maupun untuk investasi akhiratnya yang bisa disebabkan oleh bargaining position 
pembeli lebih kuat sehingga dia mendikte harga yang terjadi di pasar. Ini berarti pembeli menganiaya penjual. Kezaliman lainnya dalam penetapan harga jual terjadi karena besarnya keuntungan tidak cukup untuk memelihara lingkungan, baik lingkungan alam maupun umat manusia di sekitar perusahaan beroperasi.

Dengan memperhatikan kebutuhan ketiga komponen tersebut, yaitu pembeli, penjual (pedagang), dan lingkungan, maka baik penjual maupun pembeli bahkan masyarakat di sekitarnya akan merasakan keadilan dan kenyamanan dalam bertransaksi. Akibatnya, akan tercipta masyarakat atau daerah baldatun thayyibatun wa rabbun qhafur - negeri yang baik, aman, dan sentosa buat semua penduduknya serta Tuhan melimpahkan anugerah-Nya (QS. as-Saba' [34]). Dan bukan menjadi masyarakat yang egois, yang hanya mementingkan dirinya (Nash, 2007), tidak mau membantu sesamanya (Chapra, 1999 dan Qardhawi, 2000), dan tidak memperhatikan lingkungannya (Kamla et al., 2006: Asmal dan Asmal, 2007).

Apabila penetapan harga jual yang adil tidak mampu dibeli oleh konsumen pada umumnya atau tidak mampu bersaing di pasaran maka perlu dilakukan penghematan pada beberapa unsur biaya produksi dan biaya lainnya melalui cost reduction strategy. Apabila strategi ini dijalankan tetapi harga jual belum juga kompetitif atau tidak mampu dipenuhi pembeli pada umumnya, maka dapat dilakukan pengurangan kualitas kebutuhan dasar pedagang (penjual) yang propan dan kebutuhan bekal di akhirat yang sifatnya sunnah atau dihilangkan. Demikian juga halnya dengan santunan kepada masyarakat miskin di sekitar perusahaan dapat dikurangi.

Dengan demikian, dari aspek ontologi, terjadi perbedaan pandangan Islam dengan pandangan konvensional tentang keuntungan, pertama, pada pandangan Islam, penentuan besarnya keuntungan yang diperoleh dari kebutuhan pokok penjual dan untuk kemaslahatan lingkungan sedangkan dalam pandangan konvensional, penentuan besarnya keuntungan diperoleh dari cost of capital. Kedua, dalam pandangan Islam, keuntungan yang diperoleh sudah jelas peruntukannya, yaitu untuk kebutuhan dunia (profan), investasi akhirat, dan pemeliharaan lingkungan, sementara dalam pandangan konvensional, peruntukan margin yang diperoleh diserahkan sepenuhnya kepada pedagang.

\section{Menggapai Kemaslahatan Melalui Konsep Harga Jual Keadilan}

Keadilan adalah prasyarat bagi keselamatan dan di dalam perniagaan, keadilan itu diibaratkan sebagai saluran keselamatan modal (al-Ghazali, 2008). Keadilan di dalam perniagaan akan dapat membantu pengusaha dan pelanggan untuk memenuhi hak dan kebutuhan hidupnya serta kepantasan dalam memperoleh imbalan (Hartropp, 2010). Dengan demikian, keadilan mendorong umat manusia untuk memperlakukan umat lainnya dan lingkungan di sekitarnya secara seimbang sehingga terjadi keharmonisan hidup. 


\section{a. Hidup Tawaddhu}

Hidup dalam kesetaraan akan menghindari pemaksaan kehendak pihak tertentu, khususnya mereka yang hidup bergelimang harta untuk memenuhi keinginannya. Sementara yang lain tidak berdaya dan terpaksa harus memenuhi kemauan mereka guna memenuhi kebutuhan hidupnya meskipun terkadang bertentangan dengan norma-norma etika dan agama. Mendapatkan keuntungan sesuai kebutuhan akan mendorong mereka yang kurang mampu untuk memenuhi kebutuhan hidupnya tanpa merasa mendapat bantuan secara langsung. Setiap umat manusia tidak ada yang diagungkan yang bisa menjerumuskan ke penyembahan kepada sesama umat dan tidak ada umat yang direndahkan martabatnya yang bisa memunculkan sifat kesombongan. Akibatnya tercipta kehidupan yang lebih rendah diri dan hanya mengagungkan kebesaran Allah swt.

\section{b. Kehidupan Harmonis}

Kehidupan harmonis merupakan dambaan setiap mahluk, baik umat manusia maupun mahluk lainnya yang diciptakan Allah untuk memenuhi kebutuhan hidup umat manusia. Harmonisasi kehidupan akan tercipta jika semua mahluk hidup mampu bertahan hidup dengan memenuhi kebutuhannya secara mandiri. Konsep harga jual berbasis keadilan ini akan memacu kearah kehidupan tersebut. Betapa tidak, konsep harga ini memperhatikan kebutuhan pokok penjual, daya beli masyarakat secara umum, dan untuk menjaga pelestarian lingkungan hidup dimana perusahaan beroperasi. Dengan demikian, semua mahluk akan hidup dan berkembang secara damai dan mandiri tanpa ada yang teraniaya atau termarjinalkan.

\section{c. Meningkatkan Martabat}

Kebiasaan sebagian masyarakat, khususnya yang tidak mampu untuk melakukan perbuatan meminta-minta merupakan perbuatan yang merendahkan martabat mereka. Meskipun disadari dengan cara ini mereka bisa memenuhi kebutuhan hidupnya. Konsep harga jual berbasis nilai keadilan ini akan berusaha meningkatkan harkat hidup umat manusia dengan memperhatikan daya beli masyarakat sedangkan para pengusaha hanya dituntut untuk memenuhi kebutuhan hidupnya. Keuntungan yang diperoleh pengusaha tidak berlebih tetapi cukup untuk memenuhi kebutuhan pokoknya. Akibatnya, masyarakat akan bisa memenuhi kebutuhan pokoknya tanpa harus merendahkan martabatnya dengan meminta-minta untuk kemudian digunakan membeli kebutuhan pokok.

\section{SIMPULAN DAN KETERBATASAN}

\section{Simpulan}

Dalam pandangan keadilan yang Islami, keuntungan yang adil bagi pemilik, apabila keuntungan tersebut dapat memenuhi kebutuhan pokok pemilik dan keluarganya. Kebutuhan tersebut meliputi kebutuhan hidup yang layak di dunia dan bekal menuju alam akhirat. Jenis kebutuhan hidup yang layak di dunia tersebut meliputi kebutuhan untuk 
hidup dengan keluarga, diantaranya: kebutuhan sandang, pangan, perumahan, transportasi, dan komunikasi, kebutuhan pendidikan untuk anak-anak mereka, kebutuhan kesehatan, dan kebutuhan keamanan, sedangkan kebutuhan untuk bekal di akhirat antara lain: kebutuhan untuk melaksanakan rukun Islam dan ibadah lainnya, yaitu haji, zakat, infaq, sedekah, wakaf, qurban, dan umroh. Kebutuhan lainnya yang perlu diperhatikan adalah kemaslahatan lingkungan alam dengan melakukan pemeliharaan dan rehabilitasi lingkungan dimana perusahaan beraktivitas.

Konsep harga jual berbasis nilai keadilan di dalam Islam berdasarkan metode bayani adalah cost-plus pofane basic needs, yaitu suatu penetapan harga jual berdasarkan seluruh biaya yang terjadi untuk mengahasilkan produk dan biaya untuk memasarkan produk serta biaya operasional lainnya ditambah kebutuhan hidup profan yang layak bagi pengusaha dan keluarganya, sedangkan berdasarkan metode burhani adalah cost-plus basic needs, yaitu cost-plus profane basic needs ditambah kebutuhan akhirat pengusaha yang meliputi zakat, haji, dan sunnah, yaitu, umrah, dan qurban. Adapun konsep harga jual berbasis nilai keadilan di dalam Islam berdasarkan metode irfani adalah cost-plus basic needs and environment, yaitu cost-plus basic needs ditambah biaya untuk pelestarian lingkungan dan untuk menjalin hubungan yang harmonis dengan masyarakat disekitarnya dan generasi mendatang.

Secara umum konsep harga jual berbasis nilai keadilan di dalam Islam adalah cost-plus basic needs, yaitu konsep harga jual yang menyeimbangkan antara kebutuhan dunia (profan) dengan kebutuhan akhirat, antara kebutuhan diri sendiri dan kemampuan pembeli, antara kebutuhan diri sendiri dengan masyarakt sekitarnya, dan antara kebutuhan diri sendiri dengan lingkungan sekitarnya. Konsep ini akan menciptakan hidup tawaddhu, kehidupan yang harmonis dengan lingkungannya, dan meningkatkan kehidupan yang lebih bermartabat.

\section{Keterbatasan}

Di dalam penelitian ini, yang menjadi obyek bahasan adalah produk kebutuhan pokok umat manusia dan tidak meneliti produk sekunder dan tertier. Disamping itu, diasumsikan besarnya kebutuhan pokok setiap pedagang dan beban pemeliharaan lingkungan setiap perusahaan relatif sama. Perbedaan yang besar akan menyebabkan perbedaan harga jual di pasaran.

\section{DAFTAR PUSTAKA}

Abdullah, Amin. 2007. Desain Pengembangan Akademik IAIN Menuju UIN: dari Pendekatan Dikotomis-Atomistik ke Integratif-Interkoneksf. Dalam Amin Abdullah, dkk. Islamic Studies dalam Paradigma Interkoneksi (Sebuah Antologi). Suka Press. Yogyakarta. 
Afzalurrahman. 1982. Muhammad sebagai Seorang Pedagang. Terjemahan Dewi Nurjulianti, dkk. 2000. Yayasan Swarna Bhumy. Jakarta.

Al-Haritsi, Jaribah bin Ahmad. 2003. Fikih Ekonomi Umar bin Al-Khathab. Khalifa. Jakarta.

Alimuddin. 2010. Digging in the Hillside: Uncovering the Motivation and Performance of Moslem Entrepreneurs. International Seminar: Towards Knowledge Society. Post-Graduate Program, Brawijaya University, $2^{\text {nd }}-3^{\text {rd }}$ March, Malang.

Alimuddin. 2011. Islamic Pricing Concept Based on Ukhuwwah Value. International Seminar and Conference on Islamic Economics: Bridging Ideal and Realities Towards Economic Development Sustainability in Emerging Islamics Countries: Islamic Economic in Macro and Micro Perspectives. Universitas Negeri Jakarta and Kolej Islam Darul Ridzuan-Malaysia, 11 - 12 October 2010, Jakarta.

Asmal, Abdul Cader dan Mohammad Asmal. 2007. Perspektif Islam tentang Lingkungan dan Kependudukan. Dalam Chapman, Audrey R., Rodney L. Petersen, dan Barbara Simith Moran. Bumi yang Berputar: Perspektif Ilmu dan Agama Mengenai Konsumsi, Populasi, dan Keberlanjutan. PT. Mizan Pustaka. Bandung.

Baydoun, N. dan Roger Willet. 1994. Islamic Accounting Theory. The AAANZ Annual Conference.

Chapra, M. Umer. 1999. Islam dan Tantangan Ekonomi; Islamisasi Ekonomi Kontemporer. Risalah Gusti. Surabaya.

Christie, Nancy, B Dyck, J Morrill, dan R Stewart. 2004. Escaping the MaterialisticIndividualistic Iron Cage: A Weberian Agenda for Alternative Radical Accounting. The Fourth Asia Pacific Interdisciplinary Research in Accounting (Apira) 2004 Conference. Singapore.

Gambling, T dan R. A. Abdel Karim. 1991. Business and Accounting Ethics in Islam. London. Mansell.

Hartropp, Anrew. 2010. Do We Know what Economic Justice is? Nuancing Our Understanding by Engaging Biblical Perspectives. Transformation: An International Journal of Holistic Mission Studies. 2(1): 75 -82.

Hill, C.W. dan T.W. Jones, 1992. Stakeholder Agency-Theory. Journal of Management Studies. 29(2): 131-54. 
Islahi, A.A. 1997. Konsep Ekonomi Ibnu Taimiyah. Bina Ilmu. Surabaya.

Kamla, R, S. Gallhofer, dan J. Haslam. 2006. Islam, Nature and Accounting: Islamic Principles and the Notion of Accounting for the Environment. Accounting Forum. 30(1): 245-265.

Mochtar. Z.H dan J.S. Kahhar. 2001. Teologi Keadilan, Perspektif Islam. Risalah Gusti. Surabaya.

Kolm, Serge-Christophe. 1995. Economic Justice: The Central Question. European Economic Review. 39: 61-73.

Kotler, Philip dan Gary Armstrong. 1996. Principles of Marketing. Printice Hall Inc. New Jersey.

Manzoor, P. S. 2003. Environment and Values: an Islamic Perspective. Manzoor, P.S. 2003. Environment and Values: an Islamic Perspective. http://www.islamonline.net/English/introducingislam/environment/topic12.sthml.

Mathis, Klaus. 2009. Efficiency Instead of Justice: Searching for the Philosophical Foundations of the Economic Analysis of Law. Law and Philosophy Library. 84. http://www.springer.com/series/6210

Nash, James A. 2007. Menuju Kebangkitan dan Reformasi Kebajikan yang Subversif: Berhemat. PT. Mizan Pustaka. Bandung.

Oguz, Orhan dan Tabakoglu, Ahmed. 1991. An Historical Approach to Islamic Pricing Policy: A Research on the Ottoman Price System and its Application. JKAU: Islamic Econ., 3: 63-79.

Omar, A. Mohd, N. Azman, dan Meera, A. K. Mydin. 2010. Islamic Pricing Benchmarking. ISRA Research Paper. No. 17/2010.

Qardhawi, Yusuf. 2006. Islam dan Sekularisme. Pustaka Setia. Bandung.

Qardhawi, Yusuf. 2000. Norma dan Etika Ekonomi Islam. Gema Insani Press. Jakarta.

Rawls, John. 1999. A Theory of Justice. Harvard University Press. Massachusetts.

Sarlo, Chris. 2010. Basic Needs. http://en.wikipedia.org/wiki/Basic_needs 
Schumacher, E.F. 1987. Kecil itu Indah: Ilmu Ekonomi yang Mementingkan Rakyat Kecil. Terjemahan S. Supomo. LP3ES. Jakarta.

Shihab, M. Quraish. 2006. Tafsir Al-Mishbah; Pesan, Kesan, dan Keserasian al-Qur'an. 3, 7, dan 11. Lentera Hati. Jakarta.

Triyuwono, Iwan. 2006. Perspektif, Metodologi, dan Teori Akuntansi Syariah, PT Raja Grafindo Persada. Jakarta. 